\title{
Effects of Pre-sowing Treatments and Abiotic Stress on the Germination of Ceratonia siliqua Seeds of Four Moroccan Biomes
}

\author{
Meriem Yatim $^{1^{*}}$, Rahal El Kahkahi ${ }^{1}$, Ikram Es-Sbata ${ }^{1}$, Taoufik El-Askri ${ }^{1}$, \\ Samia EIOirdi ${ }^{2}$, Tarik Lakhlifi ${ }^{2}$, Abdelhaq Belhaj ${ }^{2}$, \\ Majida Hafidi ${ }^{1}$ and Rachid Zouhair ${ }^{1}$ \\ ${ }^{1}$ Laboratory of Plant Biotechnology and Molecular Biology, Department of Biology, Faculty of \\ Sciences, Moulay Ismail University, B.P. 11201, Zitoune, Meknes, Morocco. \\ ${ }^{2}$ Laboratory of Ecology and Biodiversity of Wetlands Team, Department of Biology, Faculty of \\ Sciences, Moulay Ismail University, B.P. 11201, Zitoune, Meknes, Morocco.
}

\begin{abstract}
Authors' contributions
This work was carried out in collaboration among all authors. Authors $M Y, R E K$ and RZ designed the study, wrote the protocol. Authors MY and REK wrote the first draft of the manuscript. Authors MY and TEA performed the statistical analysis. Authors MY, REK, RZ, MH and AB managed the analyses of the study. Authors MY, IES, SE and TL managed the literature searches. All authors read and approved the final manuscript.

Article Information

DOI: $10.9734 / A R R B / 2020 / v 35 i 1230307$ Editor(s):

(1) Dr. Bechan Sharma, University of Allahabad, India. Reviewers:

(1) Rahmi Dianita, University of Jambi, Indonesia. (2) Awnindra Kumar Singh, ICAR - Indian Institute of Pulses Research, India. Complete Peer review History: http://www.sdiarticle4.com/review-history/62839
\end{abstract}

Original Research Article

Received 08 September 2020

Accepted 13 November 2020

Published 05 December 2020

\begin{abstract}
In order to improve the germination rate of carob seeds (Ceratonia siliqua L.), we studied the morphological characteristics of the fruits (pod and seeds, integumentary hardness and tolerance to abiotic stress of the seeds) of seven ecotypes of carob trees from four regions of Morocco. The fruits of its seven populations were studied according to seven discriminative characteristics relating to the pods (length, width, thickness, total number of seeds, total weight of the pulp, seeds per pod and yield of pods per tree) and four discriminative characteristics relating to the seeds namely length, width, thickness and total fresh weight of seeds. Integumentary hardness was evaluated by pretreating the seeds with boiling water and $95 \%$ sulfuric acid. Similarly, we also followed the evolution of water absorption by the seeds during 4 days and we evaluated on these seeds pretreated, effects of different incubation temperatures $\left(10^{\circ} \mathrm{C}, 25^{\circ} \mathrm{C}\right.$ and $\left.40^{\circ} \mathrm{C}\right)$, their tolerance to
\end{abstract}


different concentrations of $\mathrm{NaCl}$, PEG6000 (0MPa, $-0.5 \mathrm{MPa},-1 \mathrm{MPa}$ and $-1.5 \mathrm{MPa})$ and their reversibility. The morphological characterization of the fruits allowed us to group the populations studied into three groups. Soaking the carob seeds in sulfuric acid for 20 minutes improved the germination rate and time. The evolution of water absorption makes it possible to distinguish two phases. The first phase is obtained during the first 24 hours and characterized by a rapid penetration of water, and second phase which lasts over the last 72 hours and which is characterized by a slow entry of water. The optimum temperature for germination of seeds from all provenances is $25^{\circ} \mathrm{C}$. The germination behavior of carob under conditions of osmotic stress demonstrated a highly significant treatment effect (concentration of PEG6000) on the rate and mean time of germination and revealed that this species is very resistant to drought. This study also showed that, salt has a depressive effect on the average germination rate, time and length of radicles. The results of the reversibility test showed that the germination of seeds transferred from osmotic stress and salt stress $(-0.5,-1$ and $-1.5 \mathrm{MPa})$ and from the temperature of $40^{\circ} \mathrm{C}$. is totally inhibited. On the other hand, seeds transferred from a temperature of $15^{\circ} \mathrm{C}$ resume germination under optimal conditions. This study allowed us to select a variety with high yield and tolerant to various biotic constraints.

Keywords: Morphological characterization; Ceratonia siliqua; seed germination; scarification; reversibility; water stress; salt stress; temperature.

\section{INTRODUCTION}

Carob tree (Ceratonia siliqua L.) is an endemic, aromatic and medicinal plant [1] which is currently available among the most efficient forest, fruit and fodder trees in Morocco. It's biological and ecological peculiarity has been included in the national priority list as a forest resource for conservation. Indeed, it is an agrosylvo-pastoral species that can be used for the rehabilitation of degraded soils, and has ability to adapt to different edapho-climatic conditions $[2,3]$. This evergreen tree has a very high economic profitability compared to other fruit species. The carob tree is a tree-like Caesalpiniaceae, spontaneous or cultivated, and of great economic importance, it tolerates drought well, explaining its wide distribution in arid and semi-arid regions of the Mediterranean climate $[4,5,6,7]$. Abiotic stresses cause significant losses in agricultural production across the $[8,9]$. Salinity and drought in particular significantly affect crop yields in arid and semiarid regions $[10,11]$. In Morocco, soil salinization is taking on alarming dimensions by reducing arable land and threatening the food balance of these regions [12]. The introduction of indigenous species resistant to aridity, has been adopted since 1920, as one of the means used to recover degraded soils in West Asia and North Africa [13]. Seed germination is usually the most critical stage for the establishment of seedlings in domestication andor planting $[14,15,16,17]$. The study of the germination requirements of the species in combination with the physical parameters of its environment makes it possible to reason the early choice of the plant material best suited to the dry environment [18,19,20,21]. Likewise, water stress is also considered among the unfavorable factors that can affect seed germination and therefore seedling quality and yield $[22,15]$. Water stress affects several plant functions, such as stomatal conductance [23,24], photosynthesis [25,26] and leaf area [23,27] A decrease in the water content of the plant immediately results in a reduction in growth in size even before photosynthesis is affected [28]. Also it affects seed germination [29] by influencing the germination metabolism, which results in the prolongation of its duration [30]. According to Amigues et al. [31], the consequences of a drought depend on its onset period compared to the crop stage and on its duration of action. With this in mind, and in order to study the germination requirements of the seeds of the carob tree and their tolerance to abiotic constraints, we have studied the scarifying power of sulfuric acid and boiling water in combination with the main environmental constraints affecting the seed germination. In this context, we focused on the study of germination under conditions of salt, water and heat stress.

\section{MATERIALS AND METHODS}

\subsection{Sample Collection}

Seven populations of Carob tree (Ceratonia siliqua $\mathrm{L}$ ) from four regions of Morocco were studied (Table 1). The pods were harvested in August 2017 in four localities: Meknes, Fez, Marrakech and Khemisset. Samples were collected in sterile Stomacher bags and transferred for testing to the Laboratory. 
Table 1. Geographical and climatic data of the Ceratonia siliqua L. seed collection stations

\begin{tabular}{lllllll}
\hline Group & Sex & Origin & Latitude N & Longitude W & Altitude (m) & $\begin{array}{l}\text { Geographic } \\
\text { region }\end{array}$ \\
\hline P1 & Femelle & Meknes & $33^{\circ} 53^{\prime} 42^{\prime \prime}$ & $5^{\circ} 33^{\prime} 17^{\prime \prime}$ & 560 & Tray saïs \\
P2 & Femelle & Fez & $34^{\circ} 03^{\prime} 00^{\prime \prime}$ & $4^{\circ} 58^{\prime} 59^{\prime \prime}$ & 579 & Tray saïs \\
P3 & Femelle & Marrakech & $31^{\circ} 37^{\prime} 48^{\prime \prime}$ & $8^{\circ} 00^{\prime} 00^{\prime \prime}$ & 450 & High Atlas \\
P4 & Femelle & Marrakech & $31^{\circ} 37^{\prime} 48^{\prime \prime}$ & $8^{\circ} 00^{\prime} 00^{\prime \prime}$ & 450 & High Atlas \\
P5 & Femelle & Marrakech & $31^{\circ} 37^{\prime} 48^{\prime \prime}$ & $8^{\circ} 00^{\prime} 00^{\prime \prime}$ & 450 & High Atlas \\
P6 & Femelle & Khemisset & $33^{\circ} 49^{\prime} 0^{\prime \prime}$ & $6^{\circ} 4^{\prime} 0^{\prime \prime}$ & 409 & Central Board \\
P7 & Femelle & Fez & $34^{\circ} 03^{\prime} 00^{\prime \prime}$ & $4^{\circ} 58^{\prime} 59^{\prime \prime}$ & 579 & Tray saïs \\
\hline
\end{tabular}

\subsection{Morphological Characterization of Carob Fruits}

The morphological characters of the fruits (pod and seeds) were determined randomly on fifteen pods per carob tree population (Ceratonia siliqua L.). Six characteristics were measured at the pod level, namely length, width, thickness, number of seeds, fresh pod weight $(\mathrm{g})$ and yield (weight of seeds/weight of pod $\left.{ }^{*} 100\right)$. Four discriminative characteristics relating to seeds were determined: length, width, thickness and total weight of seeds /pods (g).

\subsection{Effect of Pretreatment on Germination}

The seeds of the carob tree have a thick, hard seed coat. In order to determine their optimum germination conditions, we investigated the variability in mantle hardness that might exist between seeds from different regions. Two pretreatments were carried out in comparison with the control, the first consists in soaking the seeds in boiling water at $100^{\circ} \mathrm{C}$ and for $20 \mathrm{~min}$ and the second process was carried out by immersing the seeds in concentrated sulfuric acid $\left(\mathrm{H}_{2} \mathrm{SO}_{4}\right.$ at $95 \%$ ) for $20 \mathrm{~min}$. Prior to pre-treatment, the seeds were washed with $10 \%$ bleach for 2 min and then rinsed three times with sterile distilled water. After overnight soaking at $4^{\circ} \mathrm{C}$, the seeds were germinated in the dark in plastic petri dishes containing the sterile filter paper soaked in sterile water. To study the influence of the thermal factor [32], three repetitions per treatment for a period of ten days and at a rate of 20 seeds per box were carried out at three different temperatures $\left(10^{\circ} \mathrm{C}, 25^{\circ} \mathrm{C}\right.$, and $\left.40^{\circ} \mathrm{C}\right)$. The resulting optimum temperature from this experiment will be adopted for the following experiments in our study

\subsection{Effect of Salinity on Germination}

The germination tests under salt constraints were established using the optimum germination conditions determined from the previous pretreatments. The seeds were first immersed in sulfuric acid for $20 \mathrm{~min}$, then washed in distilled water for $15 \mathrm{~min}$. Seed germination was carried out in the dark and at the optimum germination temperature $\left(25^{\circ} \mathrm{C}\right)$ in Petri dishes watered daily with distilled water containing different concentrations of $\mathrm{NaCl}(0 \mathrm{MPa},-0.5 \mathrm{MPa},-1 \mathrm{MPa}$, and $-1.5 \mathrm{MPa}$ ) [20]. The counting of germinated seeds was carried out daily, for a duration of the test of 15 days.

\subsection{Effect of Osmotic Stress on Germination}

The germination tests were carried out in the dark and at optimum germination temperature $\left(25^{\circ} \mathrm{C}\right)$ under different levels of water potentials using PEG (molar mass $=6000$ ), while maintaining a stable and uniform water potential during the entire experimental period [33]. The values of the water potential tested are $0 \mathrm{MPa}$, $0.5 \mathrm{MPa},-1 \mathrm{MPa}$ and $-1.5 \mathrm{MPa}$ [20]. The duration of the test was fixed at the period of germination which was spread over 12 days and the counting of sprouted seeds was done daily.

Three variables were used to assess the germination of the seven groups of carob:

-The final germination rate (GF) which is expressed by the ratio of the number of germinated seeds to the total number of seeds,

- The mean time to germination (TMG): TMG $=\Sigma D n / \Sigma n$, where $D$ the days from the start of the germination test, and $n$ is the number of newly germinated seeds on day $D$ [34]

- Radicle length: Radicle length measurements were also performed for each treatment during the germination test [20].

\subsection{Germination Reversibility Test}

This test looks at seeds germinated under different abiotic stresses (osmotic, saline and 
thermal) and which have not germinated. This involves transferring them again for germination under optimal conditions (sterile distilled water and $\mathrm{T}=25^{\circ} \mathrm{C}$ [32].

\subsection{Water Retention Capacity of the Seeds}

For each treatment, the fresh weight of seeds germinated at $24,48,72,96 \mathrm{~h}$ of imbibition was measured. The seeds were placed in petri dishes as described for the germination experiments, removed every 24 hours after the start of imbibition and weighed [20].

The water retention capacity is calculated as follows: Water retention capacity $=(\mathrm{P} 2-\mathrm{P} 1) / \mathrm{P} 1$ * 100

\subsection{Statistical Analysis}

Data were analyzed by Two-way ANOVA using SPSS Statistics 26 software. Means \pm standard error were calculated for the morphological parameters studied. The difference in means was compared by Tukey's test at the threshold $p \leq 0.05$ and the measurements were carried out in fifteen copies $(n=15)$. Hierarchical classification was performed using SPSS 26.0 software according to the group distance aggregation method, which is based on the proximity distance matrix. The resulting dendrogram was normalized against Pearson's correlation. However, to evaluate the effects of water stress, salinity, temperature and their interactions on different parameters of germination and seedling growth were studied. The difference in means was verified by Dunnett's test at the threshold $p \leq 0.05$. Each test is carried out in three replicates of 30 seeds per group. The presented graphs and tables were produced by Graphpad prism 6 software. The different letters on the tables and the graphs indicate a different meaning at $\mathrm{p} \leq$ 0.05 .

\section{RESULTS}

\subsection{Morphological Characterization of the Seven Groups of Carob Trees}

The morphological characterization of the fruits of seven populations of carob tree was studied. The results obtained are shown in Table 2 . The characteristics related to the size of the pods vary from one group to another. The mean values for length, width, thickness, number of seeds per pod and fresh pod weight $(\mathrm{g})$ varied from $9.947 \pm 1.047 \mathrm{~cm}(\mathrm{P} 3)$ to $21.400 \pm 1.160 \mathrm{~cm}$ (P5), from $1.600 \pm$ respectively $0.130 \mathrm{~cm}$ (P5) to $1.713 \pm 0.119 \mathrm{~cm}(\mathrm{P} 1)$, from $0.373 \pm 0.046(\mathrm{P} 2)$ to $0.653 \pm 0.062 \mathrm{~cm}$ (P5), from $7.510 \pm 0.892$ $(\mathrm{P} 4)$ to $17.133 \pm 1.187(\mathrm{P} 7)$ and $3.765 \pm 0.456 \mathrm{~g}$ ( $\mathrm{P} 2)$ at $14.650 \pm 1.137 \mathrm{~g}$. From the above, it emerges that there was a significant difference between the means of length, number of seeds per pod and fresh pod weight $(\mathrm{p} \leq 0.05)$. However, there were no significant differences in width, thickness were recorded. Regarding the seeds, the length of the seed varies between $0.606 \pm$ $0.034 \mathrm{~cm}(\mathrm{P} 4)$ and $0.807 \pm 0.046 \mathrm{~cm}(\mathrm{P} 7)$, the width varies between $0.391 \pm 0.017 \mathrm{~cm}(P 4)$ and $0.633 \pm 0.049 \mathrm{~cm}(P 7)$, the thickness seed varies between $0.287 \pm 0.035 \mathrm{~cm}(\mathrm{P} 2)$ and $2.311 \pm$ $0.244 \mathrm{~cm}$ (P5), total weight of seed per pod varies between $0.787 \pm 0.046 \mathrm{~g}(\mathrm{P} 5)$ to $3.079 \pm$ $0.280 \mathrm{~g}(\mathrm{P} 7)$ and seed yield is ranged from $21.381 \pm 1.947 \%$ (P4) and $32.595 \pm 2.348 \%$ (P7). There was a significant difference between means of the thickness of seed, total weight of seed per pod and seed yield $(p \leq 0.05)$. On the other hand, length of the seed and width are not significantly different.

The population were grouped in three groups based on the results of hierarchical studies for morphological characters (Fig. 1). The first group includes populations $\mathrm{P} 1, \mathrm{P} 2$, and $\mathrm{P} 3$ from Meknes, Fez and Marrakech. They are characterized by their small and thick pods and medium yield. The second group consists of P4 and P5, these populations of Marrakech origin are related, they are characterized by long and heavy pods with a number of seeds and reduced yield. The third group consists of P6 (Khemisset) and P7 (Fez) which is characterized by yield and fairly large number of seeds with an average size of pods.

\subsection{Effect of Scarification on Germination}

The variations in germination rates according to the different scarification pretreatments over 10 days (Fig. 2), shows that scarification with sulfuric acid allows for faster start of germination. Indeed, higher germination rates of $96.67 \%$ were obtained with scarification with sulfuric acid compared with the other pretreatments tested namely scarification with boiling water $(47.78 \%)$ and with sterile distilled water $(35.55 \%)$. These results are confirmed by analysis of variance $(p<0.05)$ which revealed a very highly significant pretreatment effect on germination rates. 
Table 2. Morphological characterization of pods and seeds of seven groups of Ceratonia siliqua L.

\begin{tabular}{|c|c|c|c|c|c|c|c|c|c|c|}
\hline \multirow[b]{2}{*}{ Group } & \multirow[b]{2}{*}{ Length (cm) } & \multicolumn{3}{|c|}{ Pods } & \multirow[b]{2}{*}{$\begin{array}{l}\text { Number of } \\
\text { seeds/ pod }\end{array}$} & \multirow[b]{2}{*}{ Yield (\%) } & \multicolumn{4}{|c|}{ Seeds } \\
\hline & & Width (cm) & $\begin{array}{l}\text { Thickness } \\
\text { (cm) }\end{array}$ & $\begin{array}{l}\text { Fresh pod } \\
\text { weight }(\mathrm{g})\end{array}$ & & & $\begin{array}{l}\text { Total weight } \\
\text { of seeds }(\mathrm{g})\end{array}$ & Length (cm) & Width (cm) & $\begin{array}{l}\text { Thickness } \\
\text { (cm) }\end{array}$ \\
\hline $\mathrm{P} 1$ & $10,300 \pm 0,720^{a}$ & $1,713 \pm 0,119^{a}$ & $0,533 \pm 0,062^{a}$ & $6,226 \pm 0,679^{a}$ & $9,867 \pm 1,167^{a}$ & $29,125 \pm 2,849^{a}$ & $1,819 \pm 0,259^{a}$ & $0,800 \pm 0,065^{a}$ & $0,607 \pm 0,026^{a}$ & $0,399 \pm 0,004^{a}$ \\
\hline $\mathrm{P} 2$ & $10,900 \pm 0,996^{a}$ & $1,420 \pm 0,041^{a}$ & $0,373 \pm 0,046^{a}$ & $3,765 \pm 0,456^{\mathrm{c}}$ & $11,200 \pm 1,042^{b}$ & $28,651 \pm 2,342^{a}$ & $1,108 \pm 0,201^{a}$ & $0,753 \pm 0,052^{a}$ & $0,573 \pm 0,046^{a}$ & $0,287 \pm 0,035^{a}$ \\
\hline P3 & $9,947 \pm 1,047^{\mathrm{a}}$ & $1,507 \pm 0,153^{a}$ & $0,513 \pm 0,064^{a}$ & $6,349 \pm 0,946^{a}$ & $10,533 \pm 1,187^{a}$ & $25,647 \pm 1,346^{b}$ & $1,639 \pm 0,210^{a}$ & $0,793 \pm 0,046^{a}$ & $0,613 \pm 0,035^{a}$ & $0,393 \pm 0,026^{a}$ \\
\hline P4 & $14,240 \pm 1,218^{b}$ & $1,712 \pm 0,083^{a}$ & $0,565 \pm 0,061^{a}$ & $11,550 \pm 1,46^{\mathrm{d}}$ & $7,510 \pm 0,892^{c}$ & $21,381 \pm 1,947^{\mathrm{C}}$ & $0,803 \pm 0,029^{a}$ & $0,606 \pm 0,034^{a}$ & $0,391 \pm 0,017^{a}$ & $1,603 \pm 0,216^{b}$ \\
\hline P5 & $21,400 \pm 1,160^{c}$ & $1,600 \pm 0,130^{a}$ & $0,653 \pm 0,062^{a}$ & $14,650 \pm 1,137^{b}$ & $8,912 \pm 0,786^{a}$ & $25,967 \pm 2,060^{b}$ & $0,787 \pm 0,046^{a}$ & $0,676 \pm 0,045^{a}$ & $0,413 \pm 0,042^{a}$ & $2,311 \pm 0,244^{\mathrm{C}}$ \\
\hline P6 & $13,080 \pm 1,022^{d}$ & $1,553 \pm 0,074^{a}$ & $0,520 \pm 0,056^{a}$ & $7,243 \pm 0,570^{\mathrm{C}}$ & $13,867 \pm 1,685^{\mathrm{e}}$ & $26,498 \pm 1,870^{b}$ & $1,919 \pm 0,188^{c}$ & $0,787 \pm 0,035^{a}$ & $0,560 \pm 0,063^{a}$ & $0,393 \pm 0,059^{a}$ \\
\hline P7 & $15,507 \pm 1,522^{\mathrm{e}}$ & $1,653 \pm 0,099^{a}$ & $0,547 \pm 0,052^{a}$ & $9,573 \pm 1,287^{\mathrm{e}}$ & $17,133 \pm 1,187^{d}$ & $32,595 \pm 2,348^{d}$ & $3,079 \pm 0,280^{b}$ & $0,807 \pm 0,046^{a}$ & $0,633 \pm 0,049^{a}$ & $0,400 \pm 0,000^{a}$ \\
\hline
\end{tabular}




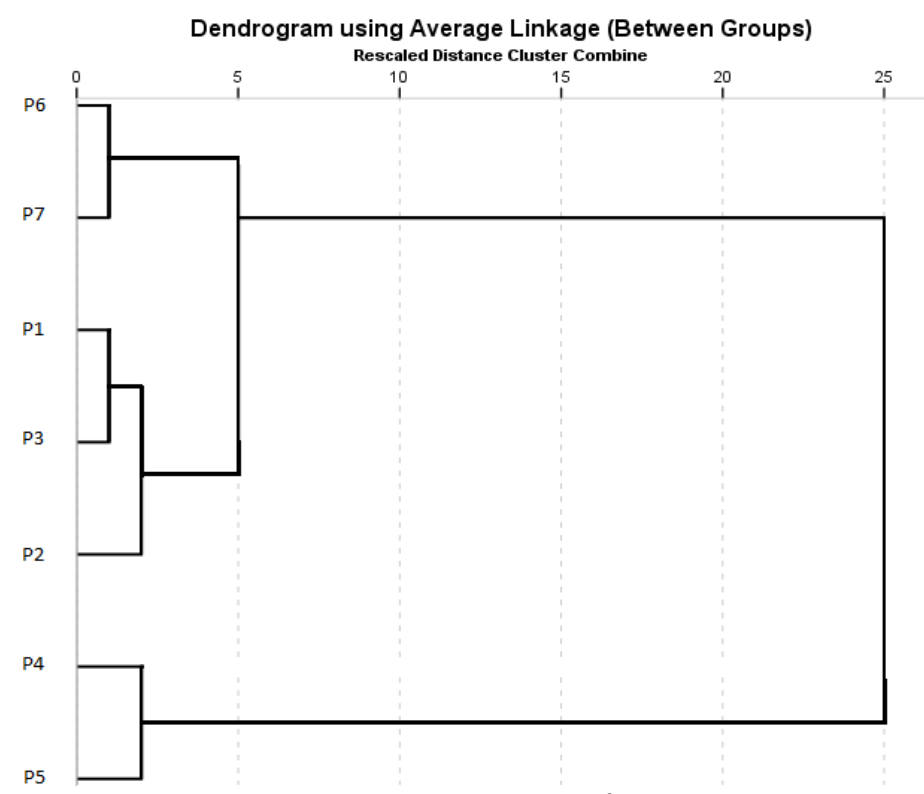

Fig. 1. Hierarchical classification according to the morphological characters of the seven groups of carob tree (Ceratonia siliqua L.)

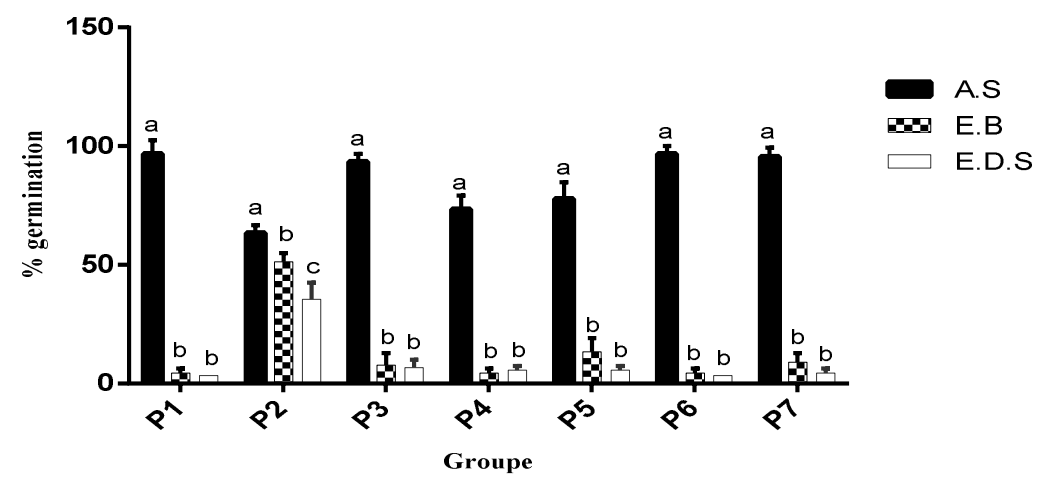

Fig. 2. Germination rate of carob seeds from four regions of Morocco under the effect of different pretreatments. EDS: sterile distilled water (Control), EB: boiling water, AS: Sulfuric acid. Different letters indicate different meaning

\subsection{Effect of Water, Salt and Heat Stress on the Water Retention Capacity of Seeds}

A separate statistical analysis was carried out for each population according to the abiotic constraints studied namely, temperature, water stress and salt stress (Figs. 3, 4 and 5). The moisture content of the seeds, measured every 24 hours, was significantly affected by temperature (Fig. 3), water potential (Fig. 4) and salt stress (Fig. 5). Regardless of the population, there are increasing reductions in water absorption over time at high and low temperatures and at low concentrations of PEG6000, and $\mathrm{NaCl}$. The evolution of water absorption makes it possible to distinguish two phases. The first phase is obtained during the first 24 hours and is characterized by a rapid penetration of water, and second phase which lasts over the last 72 hours and which is characterized by a slow entry of water. Our results also show on one hand that, the water retention capacity of seeds soaked in PEG6000 is greater than those recorded in seeds soaked with $\mathrm{NaCl}$ and on the other hand, a high absorption in seeds soaked at $15^{\circ} \mathrm{C}$ by compared to those soaked at $40^{\circ} \mathrm{C}$. 

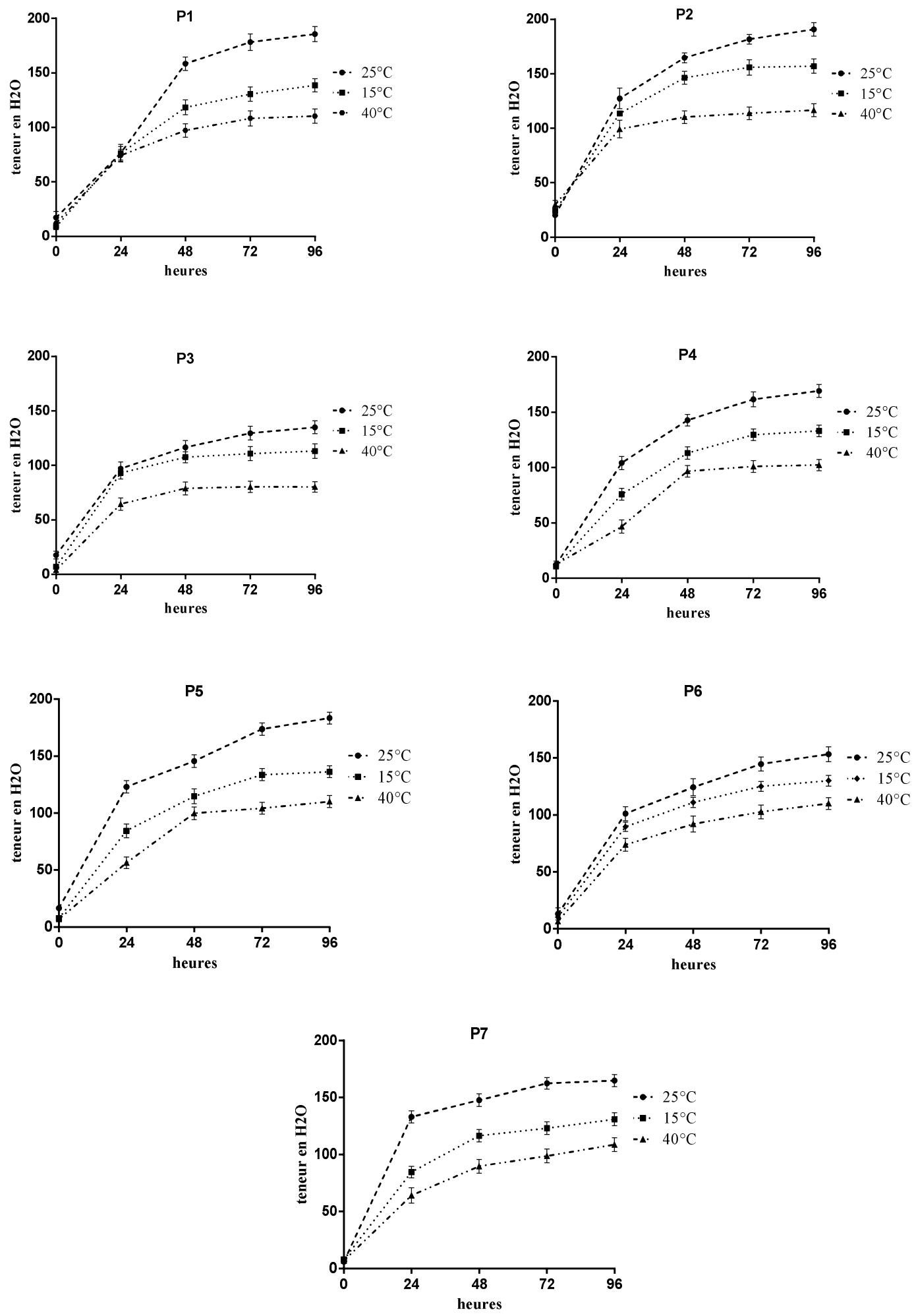

Fig. 3. Determination of the moisture content of carob seeds germinated at 10,25 and $40^{\circ} \mathrm{C}$ 
P1

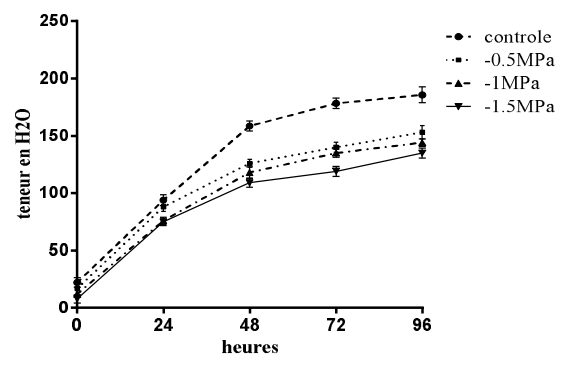

P3

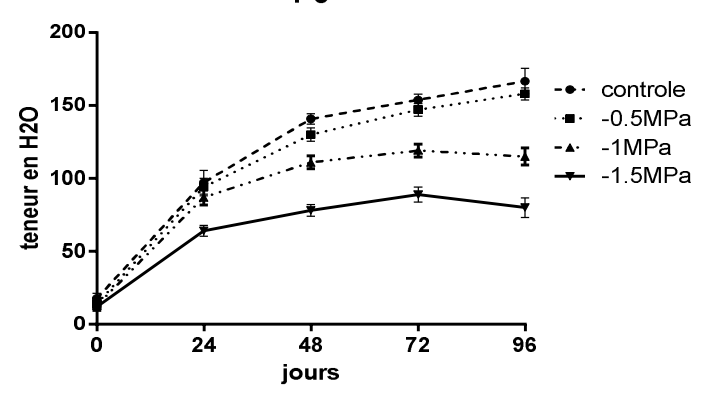

P5

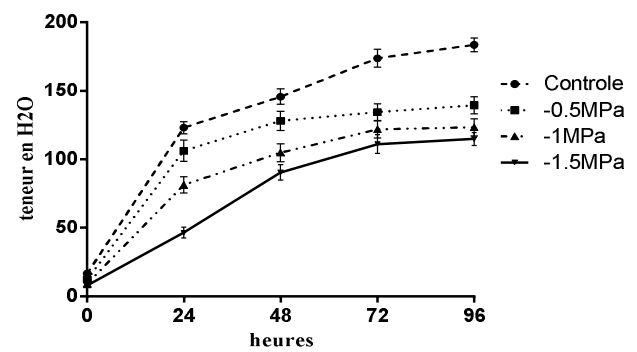

P2

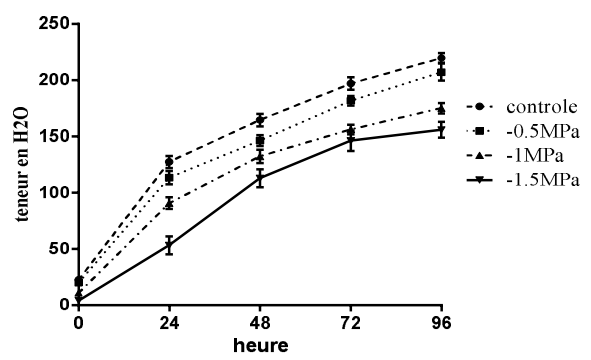

P4

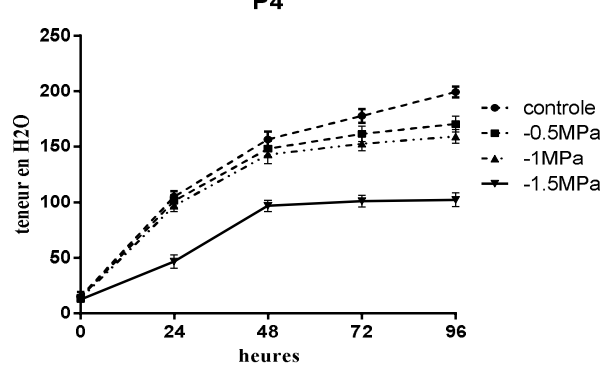

P6

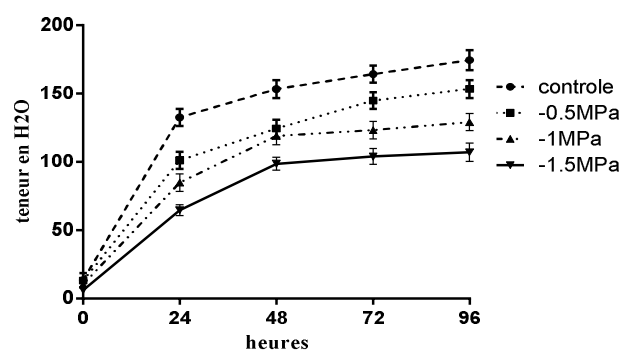

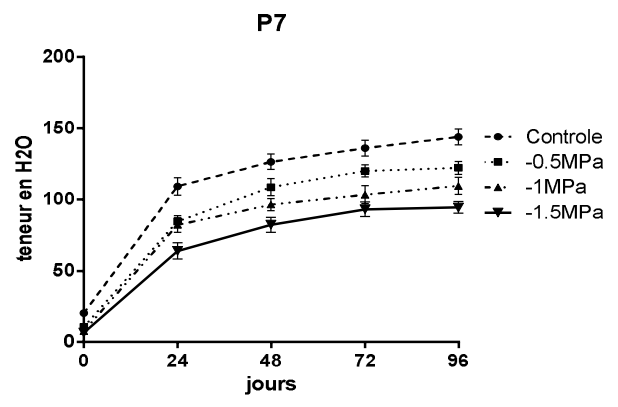

Fig. 4. Determination of the water retention capacity of carob seeds germinated at $0,-0.5,-1$ and -1.5 MPa under water stress $(p \leq 0.05)$

\subsection{Effect of Temperature on Germination}

The comparison of the average germination rates and times of seeds from different regions of Morocco as a function of temperature, shows very high seed germination rates and speeds at $25^{\circ} \mathrm{C}$. The germination power in all the populations studied varies between $93.33 \%$ to $100 \%$ for the temperature of $25^{\circ} \mathrm{C}$ and $3.33 \%$ to $17.78 \%$ for the temperature of 
$10^{\circ} \mathrm{C}$, while the seeds germinated at $40^{\circ} \mathrm{C}$ undergo inhibition thermal (Fig. 6a). The best average germination time of carob seeds under different temperatures is 3.16 days at $25^{\circ} \mathrm{C}$ (Fig. 6b). Thus, following these results obtained by these various pretreatments, the salt and water stress tests are carried out at a germination temperature of $25^{\circ} \mathrm{C}$ and with a preliminary pretreatment with sulfuric acid.
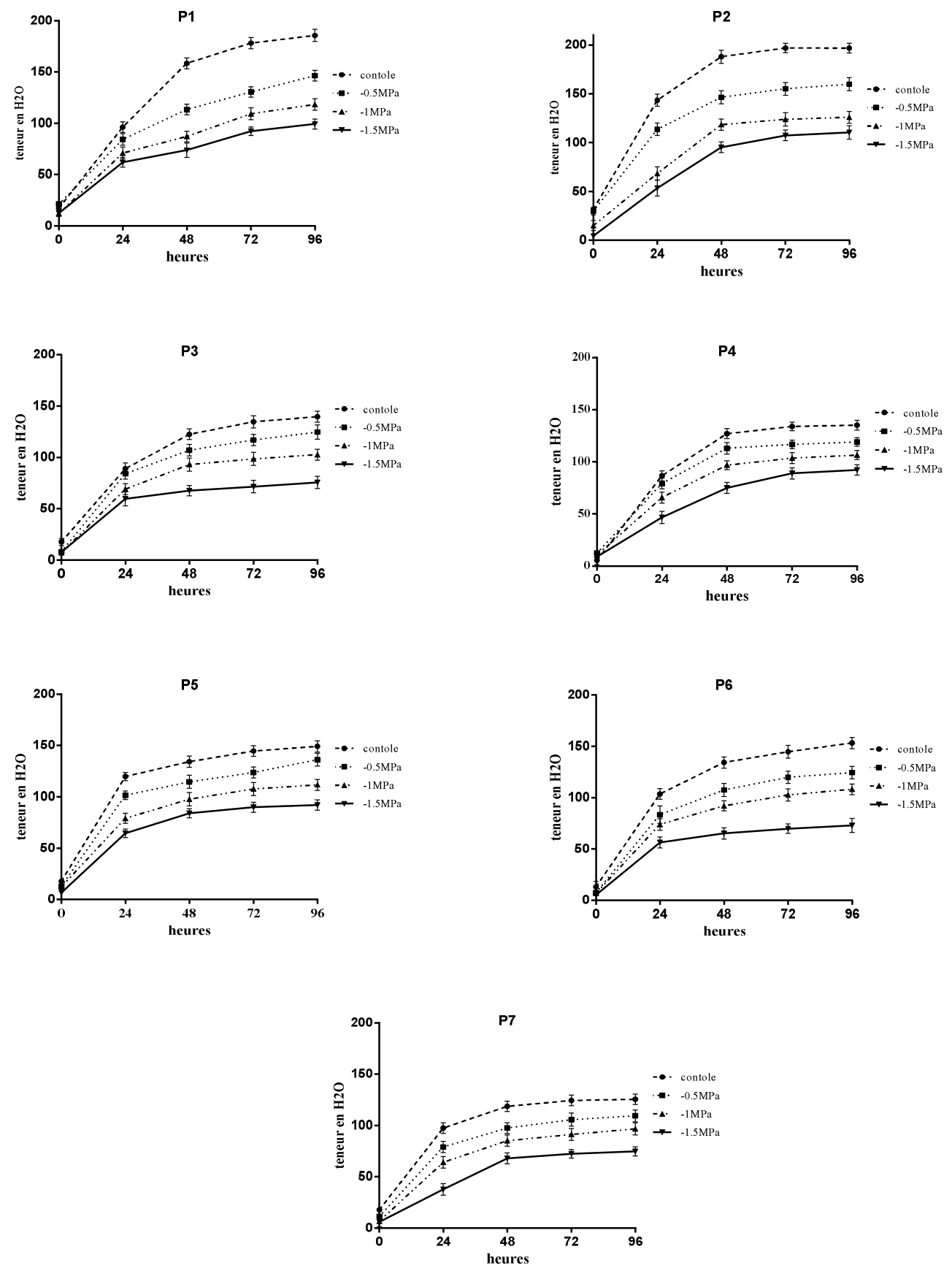

Fig. 5. Determination of the water retention capacity of carob seeds germinated under salt stress at $0,-0.5,-1$ and-1.5MPa $(p \leq 0.05)$ 
The variation in the length of the radicles of carob seeds under the effect of the different temperatures tested (Fig. 6c), also shows that the temperature $25^{\circ} \mathrm{C}$ has a remarkable effect on the length of the radicle of the seeds of the carob tree coming from different regions. Of Morocco compared to other temperatures $10^{\circ} \mathrm{C}$ and $40^{\circ} \mathrm{C}$.

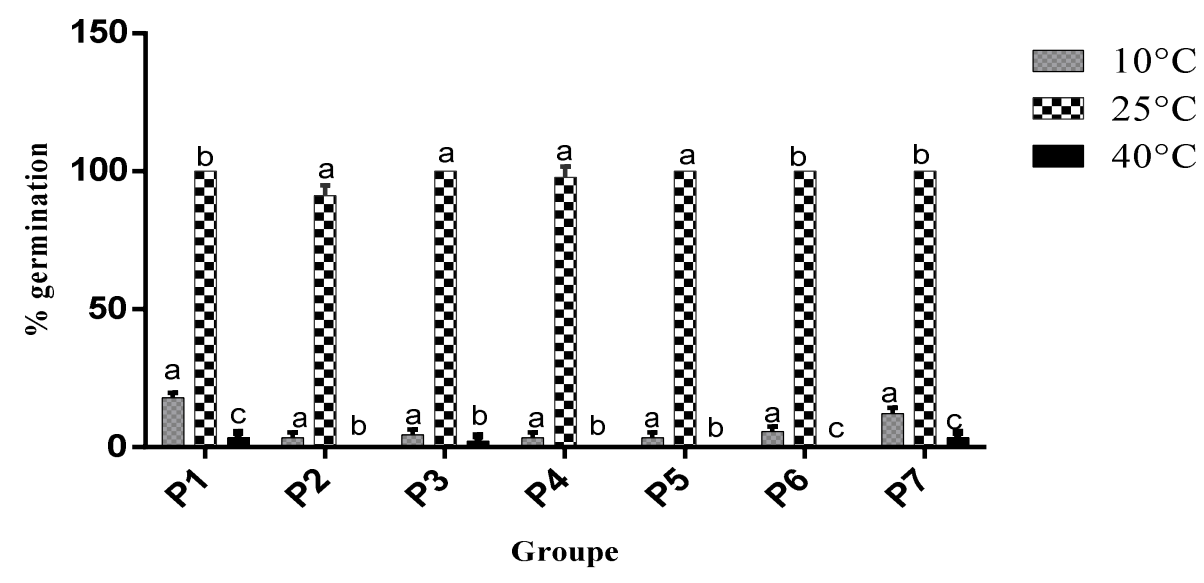

(a)

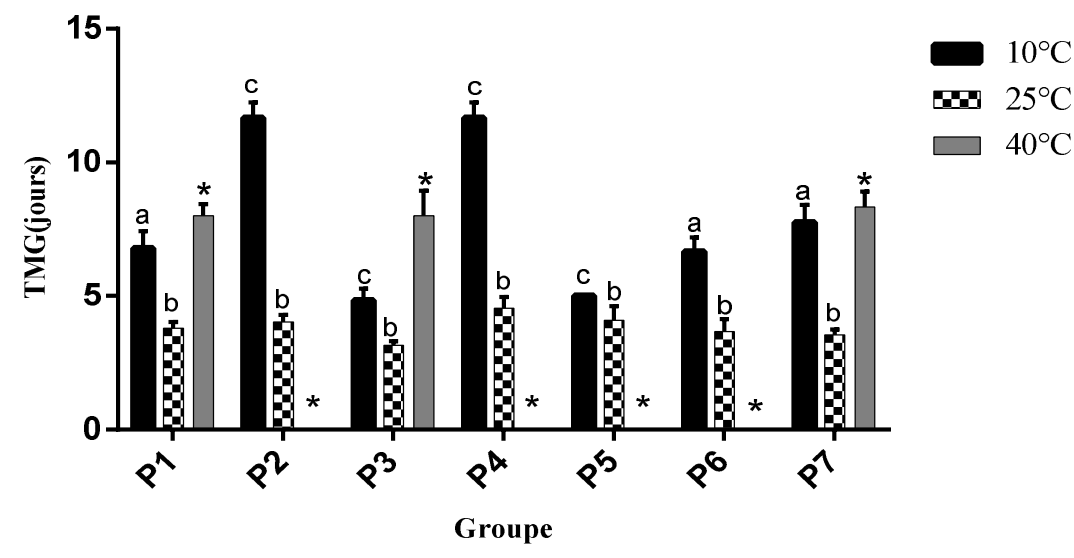

(b)

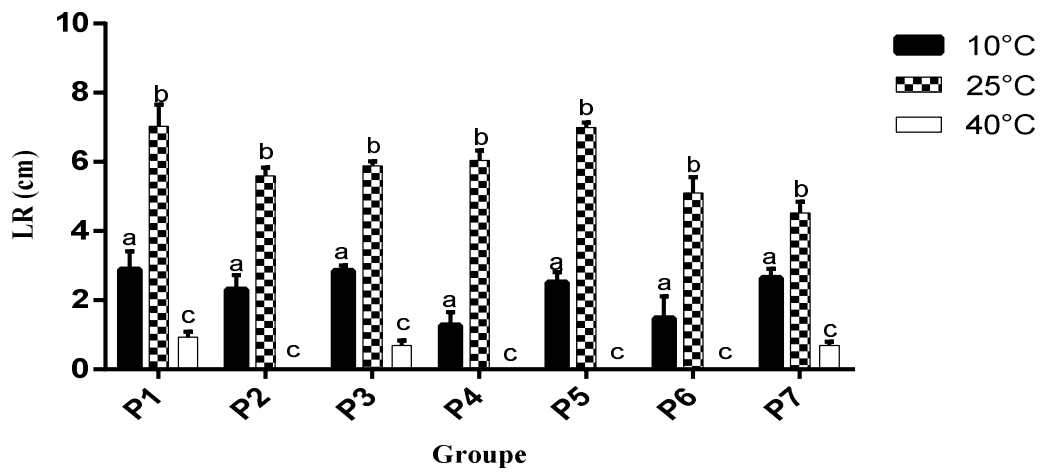

(c)

Fig. 6. (a) Germination rate, (b) Germination time), (c) Root length of carob seeds under the effect of heat stress. Different letters indicate different meanings ( $p \leq 0.05$; Dunnet's multiple comparisons test). ( ${ }^{*}$ TMG is not possible to calculate, there is no data for some row-column combinations) 


\subsection{Effect of Salinity on Germination}

The evolution of the rate and average time of germination of the seeds of the carob tree according to the increasing concentrations of $\mathrm{NaCl}$ (Fig. 7a), shows that the increase in salt stress compared to the control, leads to a reduction in the germination rates for all the seeds. Carob tree from different regions of Morocco. The germination of Ceratonia siliqua seeds is affected by $\mathrm{NaCl}$ only from the $-1 \mathrm{MPa}$ treatment $(0 \%$ germination rate). The mean germination time also lengthens depending on the intensity of the salt stress (Fig. 7b). It is only significantly affected by $\mathrm{NaCl}$ from $-1 \mathrm{MPa}$. Overall, there is a significant reduction in the length of the radicles in all the seeds from different regions of Morocco compared to the control (Fig. 7c). The $-1 \mathrm{MPa}$ concentration inhibits total seed growth.

(a)

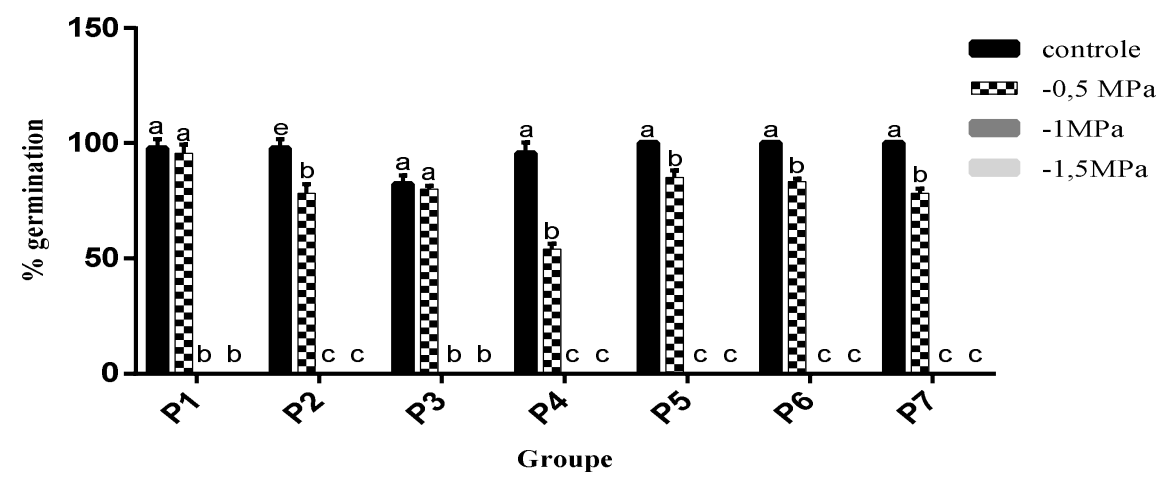

(b)
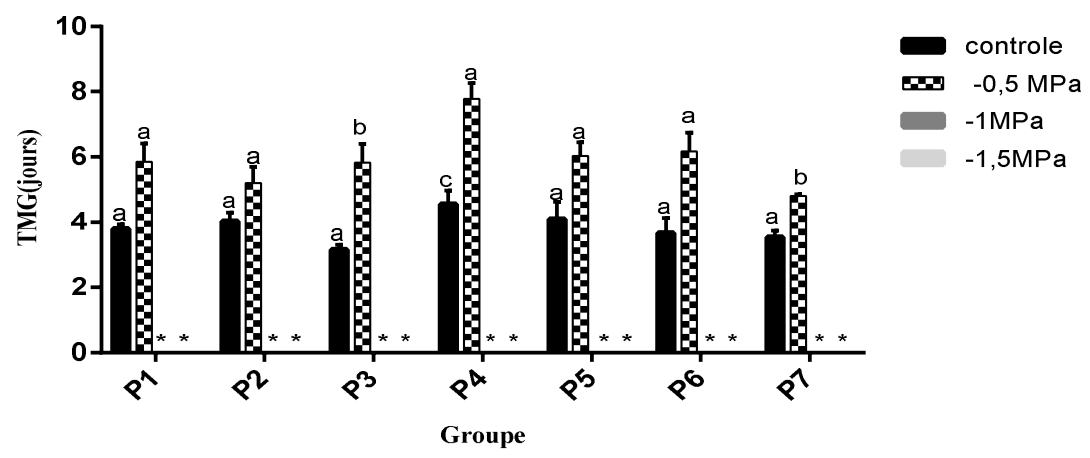

(c)

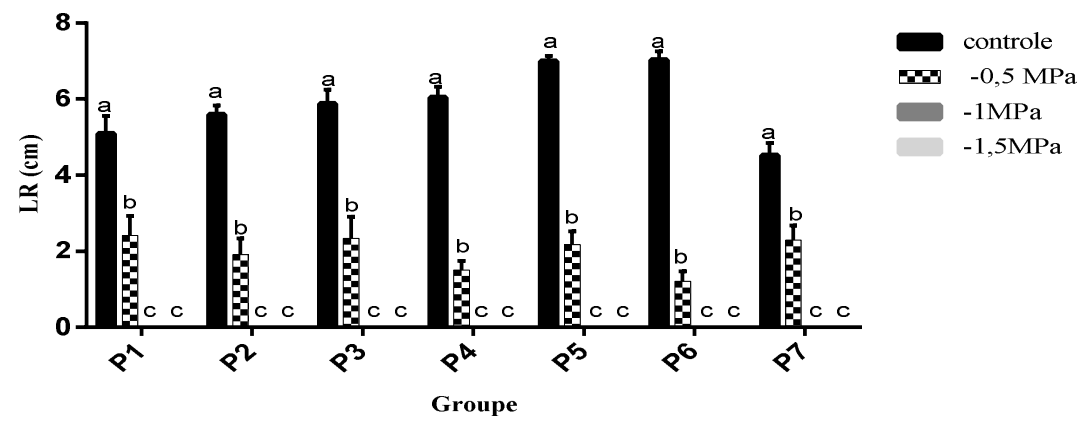

Fig. 7. (a) Germination rate, (b) Average germination time and (c) Root length of carob seeds from different regions of Morocco under the effect of different concentrations of $\mathrm{NaCl}$. Different letters indicate different meaning ( $p \leq 0.05$; Dunnett's test) 


\subsection{Effect of Water Stress on Germination}

The germination of the seeds of the seven ecotypes used in this study according to the water stress, shows that the highest germination rate is recorded in the control seeds $(100 \%)$ (Fig. 8a). Overall, for the different ecotypes and at with the exception of populations P2 and P7, it has also been observed in general that, the seed germination rate is only slightly affected by the different concentrations of PEG6000. The P2 population shows germination rate of less than $25 \%$ for the $1.5 \mathrm{MPa}$ treatment and $\mathrm{P} 7$ population shows successively germination rates of $15 \%$ and $8 \%$ at the water potential levels of $-1 \mathrm{MPa}$ and $-1.5 \mathrm{MPa}$ (Fig. 8a). For the mean germination time (Fig. $6 b)$, our data show a variation with water potential (Fig. 8b). It is about 3.8 days for the seven populations subjected to a OMPa water potential, but much longer under a water potential of $-1 \mathrm{MPa}$ and $-1.5 \mathrm{MPa}$ (6.1 days). Comparison of the average germination rates and times with Dunnett's test shows that the application of the water potential of $-1.5 \mathrm{MPa}$ significantly reduces the germination capacity, while the average germination time remains at 6.1 days. The variation in the length of the radicles of carob seeds under the effect of different water potentials also shows a progressive reduction in the length of the radicles in all carob seeds from different regions of Morocco (Fig. 8c).

\subsection{Effect of Water Stress on Germination}

The germination of seeds of the seven ecotypes used in this study according to the water stress, shows that the highest germination rate is recorded in the control seeds (100\%) (Fig. 8a). Overall, for the different ecotypes and with the exception of populations P2 and P7, we have observed that in general the seed germination rate is only slightly affected by the different concentrations of PEG6000. The P2 population shows germination rate of less than $25 \%$ for the $-1.5 \mathrm{MPa}$ treatment and the P7 population shows successively germination rates of $15 \%$ and $8 \%$ for the water potential levels of $-1 \mathrm{MPa}$ and $-1.5 \mathrm{MPa}$ (Fig. 8a). For the mean germination time (Fig. 8b), our data showed a variation with water potential (Fig. 8b). It is about 3.8 days for the seven populations subjected to a OMPa water potential, but much longer under a water potential of $-1 \mathrm{MPa}$ and $-1.5 \mathrm{MPa}$ (6.1days). Comparison of the average germination rates and times with Dunnett's test shows that the application of the water potential of $-1.5 \mathrm{MPa}$ significantly reduces the germination capacity, while the average germination time remains at 6.1 days. The variation in the length of the radicles of carob seeds under the effect of different water potentials also shows a progressive reduction in the length of the radicles in all carob seeds from different regions of Morocco (Fig. 8c).

\subsection{Germination Reversibility Test}

The germination reversibility test has been studied to determine the effect of abiotic stress on seeds. The results exhibited that the germination of seeds transferred from osmotic stress and salt stress $(-0.5,-1$ and $-1.5 \mathrm{MPa})$ and from the temperature $40^{\circ} \mathrm{C}$ is totally inhibited. On the other hand, seeds transferred from a temperature of $15^{\circ} \mathrm{C}$ resume germination under optimal conditions (sterile distilled water, $\mathrm{T}=$ $25^{\circ} \mathrm{C}$ ) for all of the seven populations studied. The germination power for all the populations studied shows germination rate which varies between 16.3 and $34.44 \%$ and an average germination time which lasts 8.19 days) (Table 3). Likewise, the length of the radicles also shows a decrease in all the seeds of the carob tree coming from different Moroccan regions.

Table 3. Effect of reversibility test of carob seed germination on rate, mean germination time and radicle length $(p \leq 0.05)$

\begin{tabular}{llll}
\hline Group & Germination rate & Average germination time & Root length \\
\hline P1 & $34,444 \pm 1,849^{\mathrm{a}}$ & $6,987 \pm 1,124^{\text {ns }}$ & $1,600 \pm 0,20^{\text {ns }}$ \\
P2 & $16,300 \pm 0,935^{\mathrm{b}}$ & $6,200 \pm 0,739^{\text {ns }}$ & $0,467 \pm 0,106^{\text {ns }}$ \\
P3 & $28,889 \pm 1,925^{\mathrm{c}}$ & $5,190 \pm 0,656^{\text {ns }}$ & $1,067 \pm 0,153^{\text {ns }}$ \\
P4 & $17,778 \pm 1,925^{\mathrm{b}}$ & $6,467 \pm 1,194^{\text {ns }}$ & $0,933 \pm 0,152^{\text {ns }}$ \\
P5 & $28,889 \pm 1,925^{\mathrm{c}}$ & $8,093 \pm 0,584^{\text {ns }}$ & $1,467 \pm 0,152^{\text {ns }}$ \\
P6 & $24,444 \pm 1,925^{\mathrm{d}}$ & $8,190 \pm 0,873^{\text {ns }}$ & $0,967 \pm 0,115^{\text {ns }}$ \\
P7 & $31,111 \pm 1,925^{\mathrm{c}}$ & $6,974 \pm 0,739^{\text {ns }}$ & $1,133 \pm 0,098^{\text {ns }}$ \\
\hline
\end{tabular}


(a)

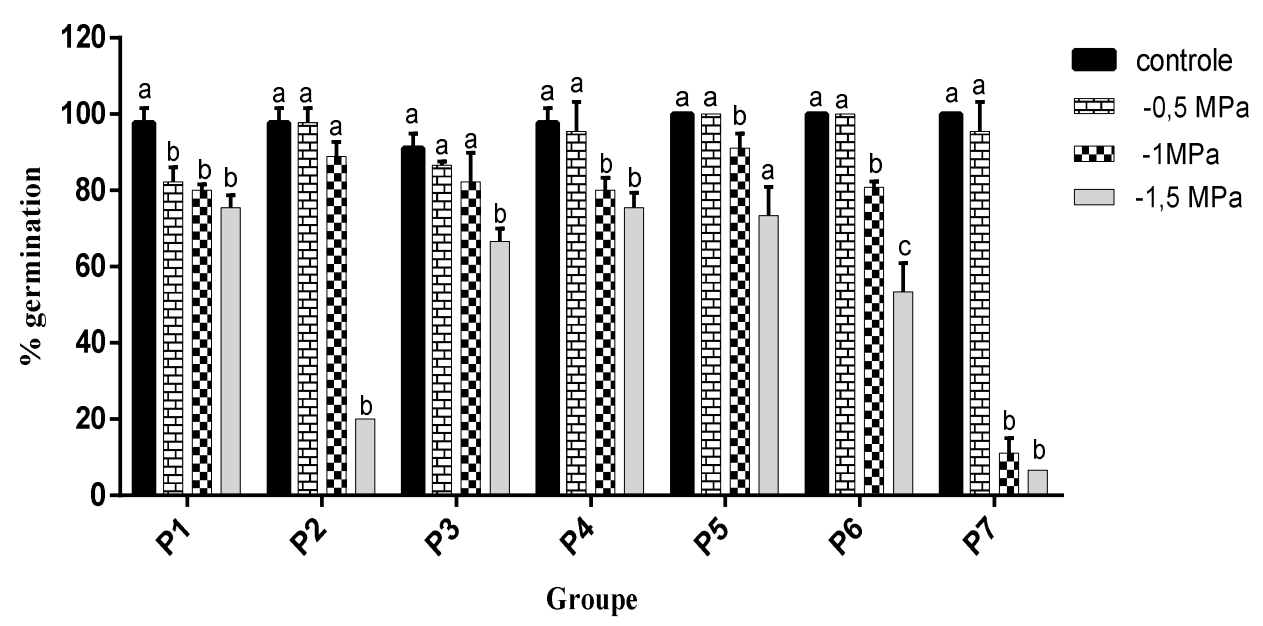

(b)

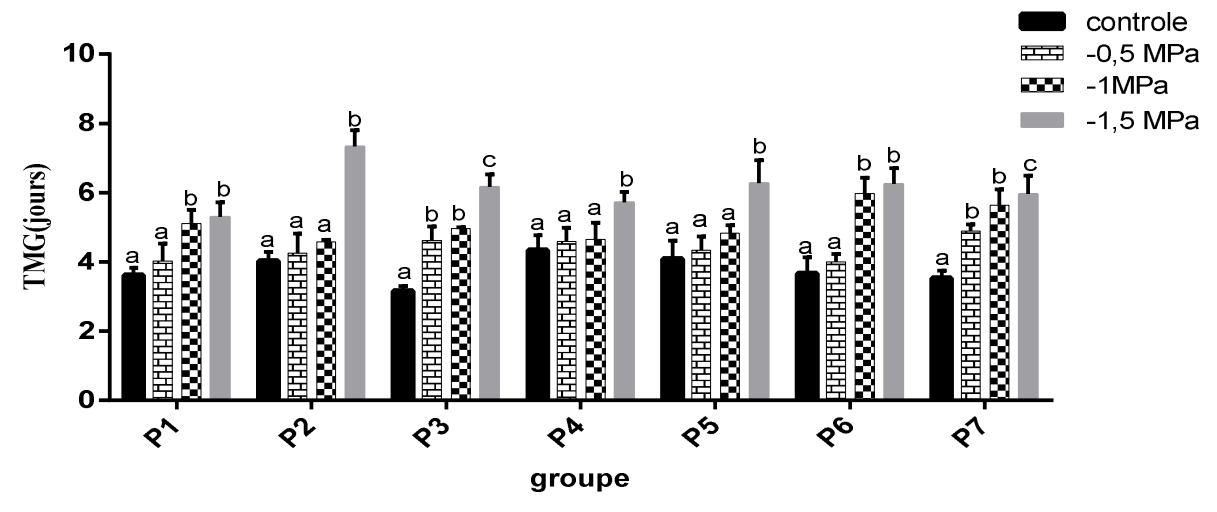

(c)

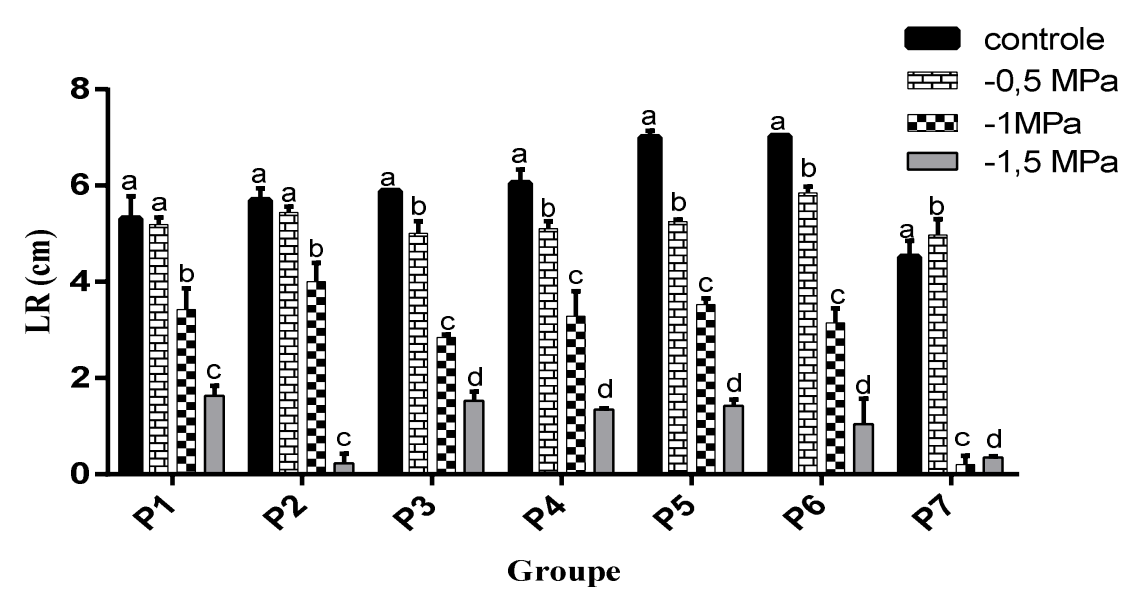

Fig. 8. (a) Germination rate, (b) Average germination times, (c) Root length of carob seeds from different regions of Morocco under the effect of different concentrations of PEG 6000 . Different letters indicate a different meanings ( $p \leq 0.05$; Dunnett's test) 


\section{DISCUSSION}

\subsection{Morphological Characterization}

In order to determine the variability of the carob tree, the study of morphological characters is commonly used $[35,36]$. The results obtained in our study are compared with those of some other countries. For 24 accessions of Syrian carob tree, they found great diversity according to the morphological criteria studied. The length, width, pod thickness, number of seeds and pod weight are respectively between 12.83 and $22.32 \mathrm{~cm}$, 1.98 and $3.12 \mathrm{~cm}, 0.58$ and $1,26 \mathrm{~cm}, 8.26$ and 16.53 and between 8.99 and $16.11 \mathrm{~g}$ [37]. The study carried out by Boublenza et al.,[38] In 2019 showed significant variability between the 10 varieties of Algerian carob, length, width, pod thickness, number of seeds and pod weight are respectively between 13.13 and $18.75 \mathrm{~cm}, 1.81$ and $3.10 \mathrm{~cm}, 0.61$ and $0.80 \mathrm{~cm}$ and between 6.79 and 13.23 and between 7.04 and $30.57 \mathrm{~g}$. In Morocco, the studies completed on the agro-morphological characterization of the Moroccan carob tree show significant phenotypic diversity $[35,36]$. In Beni Mellal (middle atlas), the carob tree population is characterized by a length of 12 and $15 \mathrm{~cm}$, width 1.5 and $2.5 \mathrm{~cm}$, pod thickness 0.4 and $1.37 \mathrm{~cm}$, number of seeds 10.67 and 12.5 [36]. In our study, the seed yield varies between 21.38 and $32.59 \%$. It is higher compared to a few Mediterranean countries (Portugal by $20 \%$ [39], Turkey $17 \%$ [40] and Algeria $14.58 \%$ [41].

\subsection{Pretreatment of Carob Seeds}

Our results showed the beneficial effect of certain pretreatments on improving the germination capacity of carob seeds. Among these pretreatments, the chemical agent (Sulfuric acid) has been shown to be necessary for the rapid and homogeneous germination of the seeds of the carob tree (Ceratonia siliqua L.). Indeed, the best results recorded were obtained with seeds treated with sulfuric acid. Thus, and for a period of 20 min of soaking the seeds in $95 \%$ sulfuric acid, we recorded the highest germination rate $(96.67 \%)$. According to Cavallaro et al., [20], germination equivalents of $100 \%$ and $95.3 \%$ were obtained for seeds of the carob tree soaked in sulfuric acid for 20 min. A germination percentage of $100 \%, \quad 93.06 \%$ and $88.89 \%$ were obtained respectively for carob seeds soaked in sulfuric acid for 30min by Kahkahi et al., [35], Güneş et al., [42] and Bostan and Kiliç, [43]. For the seeds of the carob tree and according to the authors, the duration of the treatment with sulfuric acid was very variable. It is $10 \mathrm{~min}$ for Christodoulakis et al., [44] , $20 \mathrm{~min}$ for Valeria Cavallaro et al., [20]. 30 min for Lamlom \& Abdalrasol [45], Bostan and Kilic [46], Kahkahi et al., [35], Güneş et al., [42], Pérez-García, [46], Sbay, [1] and from $45 \mathrm{~min}$ to $60 \mathrm{~min}$ for [47]. On the other hand, the use boiling water as a scarifying medium from seven provenances revealed a very low germination rate, the highest rate $(47.77 \%)$ being recorded only in the case of $\mathrm{P} 2$ accession.

\subsection{Water Retention Capacity}

Water is a necessary element for the start of the germination process. It is a source of oxygen which activates the metabolism of seeds through respiration $[48,49]$. Therefore, our results show that the absorption of water was significantly affected by the water potential of PEG6000 and $\mathrm{NaCl}$. The same results were obtained by Caruso et al. [50]. According to these authors, the absorption of water during the first hours of imbibition, in solutions of Mannitol and $\mathrm{NaCl}$, was significantly influenced at OMPa compared to other levels of osmotic pressure $(-0.25,-0.50$ and $-0.75 \mathrm{MPa}$ ). This water absorption is reduced according to the increase in the water potential of the $\mathrm{NaCl}$ and Mannitol solutions tested in two varieties of durum wheat [51]. The solution tested $-0.750 \mathrm{MPa}$ induced the lowest water absorption [51]. Note also that the water absorption in PEG solutions is lower than that recorded in $\mathrm{NaCl}$ solutions. This adequacy of water absorption was observed for seeds germinating in $\mathrm{NaCl}$ solution at $-1.5 \mathrm{MPa}$ potential and in PEG solution at $-0.5 \mathrm{MPa}$ [20]. On the other hand, our results show that the water holding capacity was also significantly affected by temperature variation. In okra seeds, it is dependent on temperature variation [32]. Water absorption which is relatively slow at $10^{\circ} \mathrm{C}$ and greater at 25 and $40^{\circ} \mathrm{C}$. According to Dkhil and Denden, [32], two distinct phases were observed, the first phase which lasts 6 hours is distinguished by a rapid entry of water whatever the temperature and a second phase of 18 hours which is characterized by a slow water absorption.

\subsection{Effect of Heat Stress on Germination}

Carob seeds from different regions of Morocco show a variation in the germination rate with respect to the thermal factor under germination 
conditions. Our results show a thermal optimum of $25^{\circ} \mathrm{C}$ for the germination of seeds of the carob tree which is similar to that of Cavallaro et al. [20]. Kahkahi et al. [35] showed that a temperature of $30^{\circ} \mathrm{C}$ allows for a high germination rate. The results of Konaté [47] also showed that the temperature $28^{\circ} \mathrm{C}$ ensures maximum germination. Likewise, germination at extreme temperatures $\left(15\right.$ and $40^{\circ} \mathrm{C}$ ) clearly affected the germination of carob seeds. Ben Dkhil and Denden in 2014 showed that extreme temperatures $\left(10\right.$ and $\left.40^{\circ} \mathrm{C}\right)$ inhibit the germination processes in okra seeds. This inhibition is explained by an inactivation of the enzymes responsible for the degradation of protein reserves at $10^{\circ} \mathrm{C}$ and by blocking the assimilation of hydrosols resulting from the degradation of reserves by the embryo at $40^{\circ} \mathrm{C}$. Our results show that temperature is one of the factors regulating germination in the carob tree.

\subsection{Effect of Salt Stress on Germination}

Tests relating to the behavior of the carob tree with respect to salinity have shown that the seeds from different provenances studied are particularly sensitive to doses of salt, in particular of $-1 \mathrm{MPa}$ of $\mathrm{NaCl}$. Indeed, the reduction of the germination rate is significant from the concentration of $-0.5 \mathrm{MPa}$ of $\mathrm{NaCl}$. These results are in agreement with those cited in the literature [52,20]. According to Caruso et al., [50], increasing salt concentrations progressively inhibit seed germination, significantly lower germination values were observed from $0.25 \mathrm{MPa}$. At a concentration of $200 \mathrm{mM}$, a depressive effect of salt on germination was noted for Medicago ciliaris Medicago intertexta and Medicago scutellata. In addition, a reduction in epicotyl and radicle length was observed in all populations for all salt doses tested [53]. Salt stress also has highly significant effects on the germination rate of Salvadora persica seeds subjected to different concentrations of $\mathrm{NaCl}$ [21]. The effect of $\mathrm{NaCl}$ on germination was also observed by Bhatt et al. [17], increasing salt concentrations reduce germination and retard the germination rate of Deverra triradiata seeds in the presence of $200 \mathrm{mM} \mathrm{NaCl}$. Gharbi et al., [54] show that $\mathrm{NaCl}$ affects the germination ability of the three species of Eucalyptus (E. gomphoecephala, E. astringenset $E$. sargentii). These authors report that Eucalyptus astringens is the most sensitive species in a range of concentrations up to $14 \mathrm{~g} / \mathrm{l}$ of $\mathrm{NaCl}$.

\subsection{Effect of Water Stress on Germination}

Water deficit is also one of the environmental factors that most often affects the germination and growth of plants $[17,55]$. Our results show that carob populations from different regions of Morocco behave differently with respect to water stress at the time of germination. Water stress, simulated by PEG6000, showed a significant effect on the germination of seeds of different genotypes of the carob tree [20]. It has an inhibitory effect on germination and radicle growth at $-1 \mathrm{MPa}$ and $-1.5 \mathrm{MPa}$. The application of osmotic stress with PEG8000 for 14 days showed a significant inhibitory effect on the germination of seeds of populations of Lotus creticus and Lotus ornithopodioides collected from different regions of Tunisia [56]. Compared to the control, the seed germination rate of $L$. creticus populations was reduced by treatments between -0.6MPa to -1.0MPa. On the other hand, in L. ornithopodioides seeds, germination is reduced to $-0.2 \mathrm{MPa}$ and it is almost inhibited with treatments of $-0.6 \mathrm{MPa}$. Our results confirm those recorded by Boubacar et al. [57]; Samb et al. [58]; Jaouadi et al. [59]. These authors have shown that the germination rate of seeds of Accacia raddiana and Tamarindus indica gradually decreases according to the water potential. The same authors show that the water potential of -8 bars deeply affects the germination of seeds. Thus, the seeds of Balanites aegyptiaca and Ziziphus mauritiana manage to germinate, but with a longer waiting period. Similar results were obtained in Ziziphus lotus [60] and [61].

\subsection{Reversibility Test}

The transfer of seeds to an optimal medium makes it possible to determine the osmotic and / or depressive effect of abiotic stress on germination [62]. The osmotic effect results in a resumption of germination once the osmotic constraints are removed. However, the high temperature and high concentrations of PEG6000 and $\mathrm{NaCl}$ inhibit germination [56]. Germination is also irreversible for Medicago polymorpha and Trifolium subterraneum at high concentrations of $\mathrm{NaCl}$ [63]. Salinity can affect the seed germination process by modifying certain enzymatic and hormonal reactions $[10,51]$. The depressive effect, on the other hand, results in a weak germination power. Thus, carob seeds transferred from a medium at a temperature of $15^{\circ} \mathrm{C}$ to a medium at a temperature of $25^{\circ} \mathrm{C}$, resume germination but 
with a germination capacity which remains quite low compared to the control. Similar results are obtained in Cicer arietinum and Abelmoschus esculentus [62,32]. For Sorghum and carob $[10,20]$ abiotic constraints have an osmotic effect on seed germination. According to Cavallaro et al. [20], the presence of the solute decreases the rate of water penetration which results in a delay or inhibition of germination. This phenomenon is not a general rule since the abiotic constraints studied in our study exert a toxic effect on the germination of seeds of seven groups of carob trees studied.

In order to demonstrate the difference between the seven populations studied, an analysis of the variance at $p \leq 0.05$ was carried out on the germination rate of the seeds under the different treatments carried out (PEG6000, $\mathrm{NaCl}$, temperature $10^{\circ} \mathrm{C}$ and $40^{\circ} \mathrm{C}$ ). With the exception of seeds under water stress at $-0.5 \mathrm{MPa}$, our results show that there is a fairly significant difference between the germination rate of control seeds and those germinated under stress. In general, we note a high germination rate for the $\mathrm{P} 1, \mathrm{P} 3, \mathrm{P} 4, \mathrm{P} 5$ and $\mathrm{P} 6$ populations which are germinated at different concentrations of PEG 6000 and for the concentration $-0.5 \mathrm{MPa}$ of $\mathrm{NaCl}$ (Table 4).

The hierarchical analysis (Fig. 9) allows us to group our seven populations of the carob tree into three groups. The first group is made up of populations $\mathrm{P} 1, \mathrm{P} 3, \mathrm{P} 4, \mathrm{P} 5$ and $\mathrm{P} 6$ coming from Meknes, Marrakech and Khemisset. This group is characterized by a high tolerance to water stress and salt stress of $-0.5 \mathrm{MPa}$. The P2 population of origin of Fez alone constitutes the second group which is characterized by a low tolerance to water stress of $-1.5 \mathrm{MPa}$, salt stress and heat stress $\left(10^{\circ} \mathrm{C}\right.$ and $\left.40^{\circ} \mathrm{C}\right)$. The third group consisting of P7 (Fez) is distinguished by a fairly low tolerance to water stress $-1 \mathrm{MPa}$ and $-1.5 \mathrm{MPa}$, salt stress and thermal stress.

Table 4. Germination rate of carob seeds from seven groups under the different stresses carried out (PEG6000, $\mathrm{NaCl}, 10^{\circ} \mathrm{C}$ and $40^{\circ} \mathrm{C}$ )

\begin{tabular}{|c|c|c|c|c|c|c|c|c|c|}
\hline Group & Control & $\begin{array}{l}-0,5 \mathrm{MPa} \\
\text { PEG }\end{array}$ & $\begin{array}{l}-1 \mathrm{MPa} \\
\mathrm{PEG}\end{array}$ & $\begin{array}{l}-1,5 \mathrm{MPa} \\
\text { PEG }\end{array}$ & $\begin{array}{l}-0,5 \mathrm{MPa} \\
\mathrm{NaCl}\end{array}$ & $\begin{array}{l}-1 \mathrm{MPa} \\
\mathrm{NaCl}\end{array}$ & $\begin{array}{l}-1,5 \mathrm{MPa} \\
\mathrm{NaCl}\end{array}$ & $10^{\circ} \mathrm{C}$ & $40^{\circ} \mathrm{C}$ \\
\hline $\mathrm{P} 1$ & $97,78^{a}$ & $82,22^{b}$ & $80,00^{b}$ & $75,56^{b}$ & $95,55^{a}$ & $0,00^{c}$ & $0,00^{c}$ & $17,78^{\mathrm{d}}$ & $3,33^{\circ}$ \\
\hline P2 & $97,78^{\mathrm{a}}$ & $97,78^{a}$ & $88,89^{b}$ & $20,00^{c}$ & $78,33^{d}$ & $0,00^{\mathrm{e}}$ & $0,00^{\mathrm{e}}$ & $3,33^{\mathrm{e}}$ & $0,00^{\mathrm{e}}$ \\
\hline P3 & $91,11^{\mathrm{a}}$ & $86,67^{a}$ & $82,22^{\mathrm{ab}}$ & $66,67^{\mathrm{c}}$ & $80,00^{\mathrm{ab}}$ & $0,00^{d}$ & $0,00^{d}$ & $4,44^{\mathrm{d}}$ & $2,22^{\circ}$ \\
\hline 24 & $97,78^{\mathrm{a}}$ & $95,56^{a}$ & $80,00^{\mathrm{b}}$ & $75,55^{\mathrm{C}}$ & $53,89^{c}$ & $0,00^{d}$ & $0,00^{d}$ & $3,33^{d}$ & $0,00^{\circ}$ \\
\hline 5 & $100,00^{\mathrm{a}}$ & $100,00^{a}$ & $91,11^{\mathrm{b}}$ & $73,33^{\mathrm{b}}$ & $85,00^{c}$ & $0,00^{\mathrm{d}}$ & $0,00^{\mathrm{d}}$ & $3,33^{d}$ & $0,00^{\circ}$ \\
\hline P6 & $100,00^{a}$ & $100,00^{\mathrm{a}}$ & $80,89^{b}$ & $53,33^{\mathrm{b}}$ & $83,33^{\mathrm{C}}$ & $0,00^{d}$ & $0,00^{d}$ & $5,56^{\mathrm{d}}$ & $0,00^{\circ}$ \\
\hline 7 & $100,00^{\mathrm{a}}$ & $95,56^{a}$ & $11,11^{\mathrm{b}}$ & $6,67^{\mathrm{c}}$ & $78,33^{d}$ & $0,00^{c}$ & $0,00^{c}$ & $12,22^{\mathrm{bc}}$ & $3,33^{\mathrm{c}}$ \\
\hline
\end{tabular}

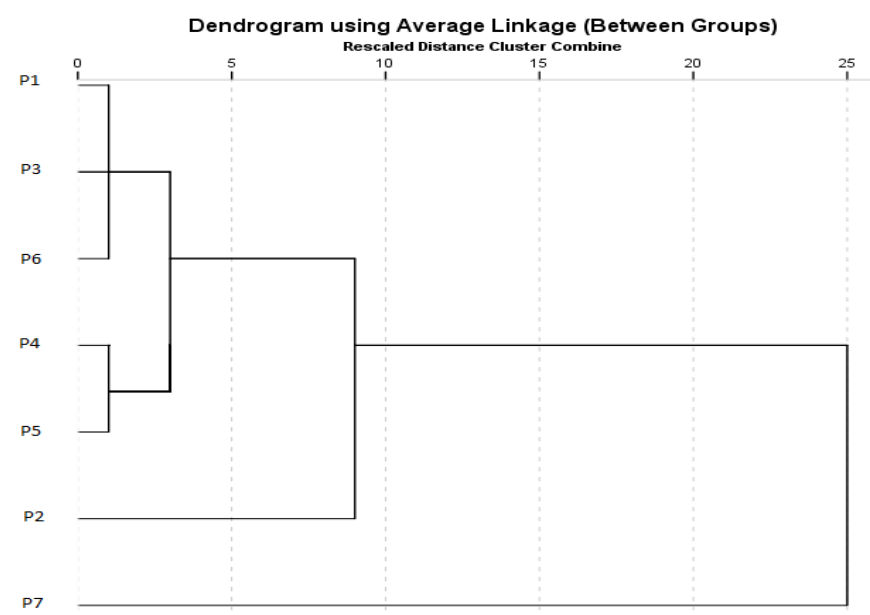

Fig. 9. Hierarchical classification of the seven groups of carob tree (Ceratonia siliqua L.) according to the germination rates of carob seeds of seven groups under the different stresses achieved $\left(\mathrm{PEG} 6000, \mathrm{NaCl}, 10^{\circ} \mathrm{C}\right.$ and $\left.40^{\circ} \mathrm{C}\right)$ 


\section{CONCLUSION}

In the light of the results obtained, it revealed that the pre-treatments showed amelioration on the germination capacity. In fact, the best results recorded were obtained with seeds treated with sulfuric acid during 20 minutes of soaking the seeds in sulfuric acid (95\%/). Our results on the effects of abiotic constraints on the germination of carob seeds from four Moroccan regions show that with the exception of populations P2 and P7, the germination of seeds of carob populations is sensitive to salt stress and tolerant to water stress $A$ decrease in the germination rate from $0.5 \mathrm{MPa}$ of $\mathrm{NaCl}$, and at osmotic pressure of 1.5MPa was recorded. The germination of carob seeds is practically inhibited at $-1 \mathrm{MPa}$ of $\mathrm{NaCl}$. Just like the germination rate and the average germination time is also affected by salt and water stress. The delay in germination increases with the severity of the stress. The evaluation of carob tree by the criterion of tolerant to abiotic constraints cannot be done solely on the basis of the response of this species in the germination phase. An investigation of the later phenological stages of this species, under constraining hydric and saline conditions, would complete these results and help to better define its pedoclimatic requirements.

\section{COMPETING INTERESTS}

Authors have declared that no competing interests exist.

\section{REFERENCES}

1. Sbay H. Le caroubier au Maroc Un arbre d'avenir. Le Centre de Recherche Forestière. Rabat; 2008.

2. Ait Chitt $M$, Belmir $M$, et Lazrak $A$. Production de plants sélectionnés et greffés de caroubier. Production Des Plantes Sélectionnés et Greffés Du Caroubier. Transfert de Technologie En Agriculture. 2007;153(037):77-80.

3. Barwick M. Tropical and subtropical trees. In: An Encyclopedia. Timber, Portland; 2004.

4. Correia PM, ML, MA. Preliminary studies on Mycorrrhizae of Ceratonia siliqua L. In New York Botanical Gardens: Mycorrhizas in integrated systems from genes to plant development. In New York Botanical Gardens: Mycorrhizas in Integrated Systems from Genes to Plant Development. NY Bronx. 1992;86-88.
5. Gullo LO, MA, Salleo S. Different strategies of drought resistance in three Mediterranean sclerophyllous trees growing in the same environmental conditions. New Phytologist. 1988;108(3), 267-276.

Available:https://doi.org/10.1111/j.14698137.1988.tb04162.x

6. Gharnit $\mathrm{N}$, El Mtili $\mathrm{N}$, Ennabili AT, EA. Social characterisation and exploitation of carob tree (Ceratonia siliqua L.) from Mokrisset and Bab Taza (NW of Morocco). Science Letters. 2001;3(2):1-10.

7. Gharnit N, El Mtili N, Ennabili A, SF. Caractérisation foliaire du caroubier (Ceratonia siliqua L.) originaire de la province de Chefchaouen (Nord-ouest du Maroc). J. Bot. Soc. Bot. France, 2005;31: 75-84.

8. Jakab G, Ton J, Flors V, Zimmerli L, MetrauxJ-Pi MMB. Responses to abiotic stresses. In: biochemistry and molecular biology of plants. American Society of Plant Physiologists, 2005 ;139:267-274.

Available:https://doi.org/10.1104/pp.105.06 5698

9. Hanumantharao B, Nair RM, Nayyar $H$. Salinity and high temperature tolerance in mungbean [Vigna radiata (L.) Wilczek] from a physiological perspective. Frontiers in Plant Science, 2016;7:1-20.

Available:https://doi.org/10.3389/fpls.2016. 00957

10. Patanè $C$, Saita $A$, Sortino $O$. Comparative effects of salt and water stress on seed germination and early embryo growth in two cultivars of sweet Sorghum. Journal of Agronomy and Crop Science. 2013; 199(1):30-37.

Available:https://doi.org/10.1111/j.1439-

037X.2012.00531.x

11. Gamalero E, Bona E, Todeschini V, Lingua G, Tecnologica I, Orientale P, Michel VT. Saline and Arid Soils: Impact on Bacteria , Plants, and their Interaction; 2020.

Available:https://doi.org/10.3390/biology90 60116

12. Kinet M, Benrebiha F, Bouzid S, Laibacar $S$, Dutuit $P$. De réseau a triplex: Allier biotechnologies et écologie pour une sécurité alimentaire accrue en régions arides et semis arides. Cahier d 'Agricultures. 1998;7 : 505-509.

13. Martins-Loução MA, Duarte PJ, Cruz C. Phenological and physiological studies during carob (Ceratonia siliqua L.) seed germination. Seed Science and 
Technology. 1996;24(1):33-47.

14. Almansouri M, Kinet $\mathrm{J}$, Lutts $\mathrm{S}$. Effect of salt and osmotic stresses on germination in durum wheat (Triticum durum Desf.). Plant and Soil 2001;231:243-254.

Available:https://doi.org/10.1023/A:101037 8409663

15. Hamrouni Lamia, Souayah Naoufel, Khouja M. Larbi, RMN. Effect of osmotic stress on Myrtus communis germination. Biologia. 2012;67(1):132-136.

Available:https://doi.org/10.2478/s11756011-0140-0

16. Walbott M, Gallet C, Corcket E. Beech (Fagus sylvatica) germination and seedling growth under climatic and allelopathic constraints. Comptes Rendus - Biologies. 2018;341(9-10):444-453. https://doi.org/10.1016/j.crvi.2018.09.003

17. Bhatt A, Bhat NR, Santo A, Phartyal SS. Influence of Temperature, Light and Salt on the Germination of Deverra Triradiata Seeds. Seed Science and Technology, 2019;47(1), 25-31.

Available:https://doi.org/10.15258/sst.2019 .47 .1 .03

18. Bell DT, Bellairs SM. Effects of temperature on the germination of selected Australian native species used in the rehabilitation of bauxite mining disturbances in Western Australia. Seed Science and Technology. 1992;20(1):4755.

Available:https://doi.org/19940606830

19. Tetsuto Abe MM. Geographic variation in germination traits in melia azedarach and Rhaphiolepis umbellata. American Journal of Plant Sciences. 2011;2(01):52-55.

Available:https://doi.org/10.4236/ajps.2011 .21007

20. Cavallaro V, Barbera AC, Maucieri C, Gimma G, Scalisi C, Patanè C. Evaluation of variabilityto drought and saline stress through the germination of different ecotypes of carob (Ceratonia siliqua L.) using a hydrotime model. Ecological Engineering, 2016 ;95:557-566.

Available:https://doi.org/10.1016/j.ecoleng. 2016.06.040

21. Hadi SMS, Ahmed MZ, Hameed A, Khan MA, Gul B. Seed germination and seedling growth responses of toothbrush tree (Salvadora persica Linn.) to different interacting abiotic stresses. Flora: Morphology, Distribution, Functional Ecology of Plants, 2018;243:45-52.

Available:https://doi.org/10.1016/j.flora.201
8.04.002

22. Larbi A, Mekliche A, Abed R, Badis M. Effet du déficit hydrique sur la production de deux variétés de blé dur (Triticum turgidum $\mathrm{L}$. var . durum ) en région semiaride. 2000;297:295-297.

23. Penuelas J, Save R, MO, SL. Remotely measured canopy temperature of greenhouse strawberries as indicator of water status and yield under mild and very mild water stress conditions. Agricultural and Forest Meteorology. 1992;58(1-2):6377.

24. Yagoubi S. Irrigation d'appoint et efficience de l'utilisation de l'eau. Cas de la pomme de terre. Centre international de hautes études agronomiques méditerranéennes, Bari (Italie). Centre International de Hautes Études Agronomiques Méditerranéennes, Bari (Italie) ; 1993.

25. Moran MS, Clarke TR, IY, VA. Estimating crop water deficit using the relation between surface-air temperature and spectral vegetation index. Remote Sensing of Environment. 1944;49(3):246-263.

26. Yuan W, Liu D, Dong W, Liu S, Zhou G, Yu G, Zhao T, Feng J, Ma Z, Chen J, Chen Y, Chen S, Han S, Huang J, Li L, Liu H, Liu S, Ma M, Wang $Y$, Zhao L. Multiyear precipitation reduction strongly decreases carbon uptake over northern China. Journal of Geophysical Research: Biogeosciences. 2014;119(5):881-896.

Available:https://doi.org/10.1002/2014JG0 02608

27. Haffani S, Mezni M, Ben Nasri M, Chaibi W. Comparative leaf water relations and anatomical responses of three vetch species (Vicia narbonensis L., V. sativa L. and $V$. villosa Roth.) to cope with water stress. Crop and Pasture Science. 2017;68(7):691-702.

Available:https://doi.org/10.1071/CP17029

28. Turner NC. Further progress in crop water relations. Advances in Agronomy. 1997;58: 293-338.

29. Belmehdi O, El Harsal A, Benmoussi M, Laghmouchi Y, Skali Senhaji N, Abrini J. Effect of light, temperature, salt stress and $\mathrm{pH}$ on seed germination of medicinal plant Origanum elongatum (Bonnet) Emb. \& Maire. Biocatalysis and Agricultural Biotechnology, 2018;16:126-131.

Available:https://doi.org/10.1016/j.bcab.20 18.07.032

30. Ramin AA. Effects of salinity and temperature on germination and seedling 
establishment of sweet basil (Ocimum basilicum L.). Journal of Herbs, Spices and Medicinal Plants, 2006; 11(4):81-90.

Available:https://doi.org/10.1300/J044v11n 04 09

31. Amigues $\mathrm{J}$, Debaeke $\mathrm{P}$, Lemaire $\mathrm{G}$, et Tardieu F. Sécheresse et agriculture Réduire la vulnérabilité de l'agriculture á un risque accru de manque d'eau. Expertise Scientifique Collective, synthèse d(January), INRA (France); 2006.

32. Ben Dkhil B, Denden M. Effet de la température sur la germination, la dégradation des réserves protéiques et minérales des graines du gombo (Abelmoschus esculentus L .). Journal of New Sciences. 2014;5(4):25-33.

33. Michel BE, Kaufmann MR. The Osmotic potential of polyethylene glycol 6000. Plant Physiology. 1973;51(5):914-916.

Available:https://doi.org/10.1104/pp.51.5.9 14

34. Gunes E, Gubbuk H, Ayala-Silva T, Gozlekci S, Ercisli S. Effects of various treatments on seed germination and growth of carob (Ceratonia siliqua L.). Pakistan Journal of Botany. 2013;45(4): 1173-1177.

35. El Kahkahi R, Zouhair R, Ait Chitt M, Errakhi R. Morocco carob (Ceratonia siliqua L .) populations: Morphological variability of Pods and Kernel. 2014;2(4): 38-47.

36. Elfazazi K, Jbilou M, Assaidi A, Benbati M, Harrak H. Morphological and biochemical variability of Moroccan Carob (Ceratonia siliqua $L$.) Produced in Beni Mellal Region. 2017;5(4):14-21.

37. Mahfoud $\mathrm{H}$, Ameen $\mathrm{T}$, Kazngi $\mathrm{F}$, Nasser S. Morphological and genetic variability of natural Syrian carob (Ceratonia Silique L.). International Journal of Agriculture \& Environmental Science. 2018;5(2):70-76.

Available:https://doi.org/10.14445/2394256 8/ijaes-v5i2p110

38. Boublenza I, El A, Ghezlaoui S, Mahdad M, Vasaï F, Chemat F. Scientia Horticulturae Algerian carob (Ceratonia siliqua L .) populations . Morphological and chemical variability of their fruits and seeds. Scientia Horticulturae. 2019; 108537.

Available:https://doi.org/10.1016/j.scienta.2 019.05.064
39. Barracosa $\mathrm{P}$, Lima MB, Cravador A. Analysis of genetic diversity in Portuguese Ceratonia siliqua L. cultivars using RAPD and AFLP markers. Scientia Horticulturae. 2008;118(3):189_ 199.

40. Pazir F, Engineering F. Carob bean (Ceratonia siliqua L.) and Its Products. Anadolu Ege Tarımsal Araştırma Enstitüsü Dergisi, 2018;28(1): 108-112.

41. Boublenza I, El haitoum A, Ghezlaoui S, Mahdad M, Vasaï F, Chemat F. Algerian carob (Ceratonia siliqua L.) populations. Morphological and chemical variability of their fruits and seeds. Scientia Horticulturae. 2019;256:108537.

Available:https://doi.org/10.1016/j.scienta.2 019.05.064

42. Güneş E, Gübbük H, Yaşin D. The effect of different sulfuric acid concentrations on seed germination of carob (Ceratonia siliqua L.). Bulletin of University of Agricultural Sciences and Veterinary Medicine Cluj-Napoca - Horticulture, 2010; 66(1):687.

Available:https://doi.org/10.15835/buasvmc n-hort:4520

43. Bostan SZ, Kiliç D. The effects of different treatments on carob (Ceratonia Siliqua L.) seed germination. Türk Tarım ve Doğa Bilimleri Dergisi. 2014;1(Özel Sayı-1): 706-708.

Available:https://dergipark.org.tr/en/pub/tur kjans/issue/13310/160806

44. Christodoulakis NS, Menti J, Galatis B. Structure and development of stomata on the primary root of Ceratonia siliqua L. Annals of Botany. 2002;89(1):2329.

Available:https://doi.org/10.1093/aob/mcf0 02

45. Lamlom SH, Abdalrasol EM. Effects of Various pre-sowing treatments on seed germination of carob (Ceratonia Siliqua L.) from Al-Jabal Al-Akhdar area (Balagrae, Al-Baida, Libya). IOSR Journal of Agriculture and Veterinary Science. 2016; 09(09):16-24.

Available:https://doi.org/10.9790/23800909011624

46. Pérez-García F. Germination characteristics and intrapopulation variation in carob (Ceratonia siliqua L.) seeds | Características germinativas y variación intrapoblacional en semillas de algarrobo (Ceratonia siliqua L.). Spanish 
Journal of Agricultural Research. 2009;7(2).

47. Konate I. Diversité phenotypique et moleculaire du caroubier (Ceratonia siliqua L.) et des Bactéries endophytes qui lui sont associées. Université Mohammed V-Agdal Faculté Des Sciences Rabat, Thèse de Doctorat; 2007.

48. Patanè C, Cavallaro V, Avola G, D'Agosta G. Seed respiration of sorghum [Sorghum bicolor (L.) Moench] during germination as affected by temperature and osmoconditioning. Seed Science Research. 2006;16,(4):251-260.

DOI:10.1017/SSR2006259

49. Cavallaro V, Maucieri C, Barbera AC. Lolium multiflorum Lam: Cvs germination under simulated olive mill wastewater salinity and $\mathrm{pH}$ stress. Ecological Engineering. 2014;71:113-117.

Available:https://doi.org/10.1016/j.ecoleng. 2014.07.055

50. Caruso C, Maucieri C, Berruti A, Borin M, Barbera A. Responses of different Panicum miliaceum L. genotypes to saline and water stress in a marginal Mediterranean environment. Agronomy. 2018;8(1):8.

Available:https://doi.org/10.3390/agronomy 8010008

51. Maucieri C, Caruso C, Bona S, Borin M, Barbera AC, Cavallaro V. Influence of salinity and osmotic stress on germination process in an old sicilian landrace and a modern cultivar of Triticum Durum Desf. Cereal Research Communications. 2018; 46(2):253-262.

Available:https://doi.org/10.1556/0806.46.2 018.07

52. Medjebeur D, Hannachi L, Ali-Ahmed S, Metna B, Abdelguerfi A. Effets de la salinité et du stress hydrique sur la germination des graines de Hedysarum flexuosum (Fabaceae). Revue d'écologie. 2018;73(3):318-329.

53. Mbarki S, Skalicky M, Vachova $P$, Hajihashemi S, Jouini L, Zivcak M, Tlustos $P$, Brestic M, Hejnak V, Khelil AZ. Comparing salt tolerance at seedling and germination stages in local populations of medicago ciliaris $\mathrm{L}$. To medicago intertexta L. and Medicago scutellata L. Plants, 2020; 9(4).

Available:https://doi.org/10.3390/plants904 0526

54. Gharbi F, Kchaou R, Rejeb S, KL, et RM.
Tolérance à la Salinité de Trois Espèces d"Eucalyptus aux Stades Germinatif et Plantule. European Journal of Scientific Research. 2011;(2):208-217.

55. Lhlou B, Omari PF, Dahan R, Van Damme $\mathrm{P}$, Benkirane R, BH. Evaluation de l'effet du stress hydrique et du porte-greffe sur la clémentine Citrus reticulata Swingle var. Sidi Aissa. Journal of Applied Biosciences. 2013;71:5692-5704.

Available:https://doi.org/10.4314/jab.v71i1. 98813

56. Hajri R, Ouhibi C, Mechri M, Kourda H, Younes M. Ben. Salinity and water deficit effects on seed germination and recovery of lotus populations from northern Tunisia. Pakistan Journal of Botany. 2018;50(6): 2085-2090.

57. Boubacar AA, Douma S, Diouf A. Effets du stress hydrique et de la température sur la germination de quatre ligneux alimentaires prioritaires du Niger Résumé. Afrique Science. 2018;14(3):28-41.

58. Samb C, Niang M, Samba A, Sall M, Cisse $\mathrm{N}$, Diouf M, Van Damme P. Etude de la germination de cinq provenances de Tamarindus indica L. en conditions de stress hydrique au Sénégal. International Journal of Biological and Chemical Sciences. 2015;9(2):838.

Available:https://doi.org/10.4314/ijbcs.v9i2. 23

59. Jaouadi W, Hamrouni L, Souayeh N, Khouja ML. Etude de la germination des graines d'Acacia tortilis sous différentes contraintes abiotiques. Biotechnology, Agronomy and Society and Environment. 2010;14(4):643-652.

60. Wahbi J. Effet des contraintes hydrique et saline sur la germination de trois espèces d'acacias en Tunisie. Rev. Écol. (Terre Vie), 2012;67:1-10.

61. Zouaoui Refka, Mustapha K, Ali F. Effet de l'intensité de la contrainte hydrique sur la germination de Ziziphus Lotus ( L. ) Lam. des Régions Arides de la Tunisie. Algerian Journal of Arid Environment. 2013;3(1): 35-49.

Available:https://doi.org/10.12816/0008888

62. Hajlaoui $H$, Denden M, Bouslama M. Etude de la variabilité intraspécifique de tolérance au stress salin du pois chiche (Cicer arietinum L.) au stade germination. Tropicultura, 2007;25(3):168173.

63. Nichols PGH, Malik AI, Stockdale M, Colmer TD. Salt tolerance and avoidance 
mechanisms at germination of annual pasture legumes: Importance for adaptation to saline environments. Plant and Soil. 2009;315(1-2), 241-255.

Available:https://doi.org/10.1007/s11104008-9747-5

(c) 2020 Yatim et al.; This is an Open Access article distributed under the terms of the Creative Commons Attribution License (http://creativecommons.org/licenses/by/4.0), which permits unrestricted use, distribution, and reproduction in any medium, provided the original work is properly cited.

Peer-review history:

The peer review history for this paper can be accessed here: http://www.sdiarticle4.com/review-history/62839 